\title{
Differential effects of formoterol on thrombin- and PDGF-induced proliferation of human pulmonary arterial vascular smooth muscle cells
}

Elena A Goncharova ${ }^{1,2,4^{*}}$, Irene S Khavin', Dmitry A Goncharov and Vera P Krymskaya ${ }^{1,2,3}$

\begin{abstract}
Background: Increased pulmonary arterial vascular smooth muscle (PAVSM) cell proliferation is a key pathophysiological component of pulmonary vascular remodeling in pulmonary arterial hypertension (PH). The long-acting $\beta_{2}$-adrenergic receptor ( $\left.\beta_{2} A R\right)$ agonist formoterol, a racemate comprised of $(R, R)$ - and $(S, S)$-enantiomers, is commonly used as a vasodilator in chronic obstructive pulmonary disease (COPD). PH, a common complication of COPD, increases patients' morbidity and reduces survival. Recent studies demonstrate that formoterol has anti-proliferative effects on airway smooth muscle cells and bronchial fibroblasts. The effects of formoterol and its enantiomers on PAVSM cell proliferation are not determined. The goals of this study were to examine effects of racemic formoterol and its enantiomers on PAVSM cell proliferation as it relates to COPD-associated PH.

Methods: Basal, thrombin-, PDGF- and chronic hypoxia-induced proliferation of primary human PAVSM cells was examined by DNA synthesis analysis using BrdU incorporation assay. ERK1/2, mTORC1 and mTORC2 activation were determined by phosphorylation levels of ERK1/2, ribosomal protein S6 and S473-Akt using immunoblot analysis.

Results: We found that $(R, R)$ and racemic formoterol inhibited basal, thrombin- and chronic hypoxia-induced proliferation of human PAVSM cells while $(S, S)$ formoterol had lesser inhibitory effect. The $\beta_{2} A R$ blocker propranolol abrogated the growth inhibitory effect of formoterol. $(R, R)$, but not $(S, S)$ formoterol attenuated basal, thrombin- and chronic hypoxia-induced ERK1/2 phosphorylation, but had little effect on Akt and S6 phosphorylation levels. Formoterol and its enantiomers did not significantly affect PDGF-induced DNA synthesis and PDGF-dependent ERK1/2, S473-Akt and S6 phosphorylation in human PAVSM cells.

Conclusions: Formoterol inhibits basal, thrombin-, and chronic hypoxia-, but not PDGF-induced human PAVSM cell proliferation and ERK1/2, but has little effect on mTORC1 and mTORC2 signaling. Anti-proliferative effects of formoterol depend predominantly on its $(R, R)$ enantiomer and require the binding with $\beta_{2} A R$. These data suggest that $(R, R)$ formoterol may be considered as potential adjuvant therapy to inhibit PAVSM cell proliferation in COPD-associated PH.
\end{abstract}

Keywords: $(R, R)$ formoterol, ERK1/2, Pulmonary hypertension

\footnotetext{
* Correspondence: goncharo@mail.med.upenn.edu

${ }^{1}$ Pulmonary, Allergy \& Critical Care Division, Department of Medicine,

University of Pennsylvania Perelman School of Medicine, Philadelphia, PA,

USA

${ }^{2}$ Penn Cardiovascular Institute, University of Pennsylvania, Philadelphia, PA,

USA

Full list of author information is available at the end of the article
} 


\section{Background}

Pulmonary arterial vascular smooth muscle (PAVSM) cell proliferation is one of the key pathophysiological components of vascular remodeling in pulmonary hypertension $(\mathrm{PH})[1,2] . \mathrm{PH}$ is a common complication of chronic obstructive pulmonary disease (COPD), which is strongly associated with decreased quality of life, increased morbidity and reduced survival of COPD patients $[3,4]$. The major pathological manifestations of $\mathrm{PH}$ are vasoconstriction and remodeling of small muscular pulmonary arteries (PA). Prolonged exposure to hypoxia, growth factors and pro-inflammatory cytokines induces PAVSM proliferation and pulmonary vascular remodeling leading to persistent elevation of pulmonary vascular resistance, right ventricular failure and death $[2,5,6]$. Systemic vasodilators, however, have not been found to be effective therapy for COPD-associated $\mathrm{PH}$ [6] and therapeutic options to target pulmonary vascular remodeling are needed.

$\beta_{2}$ adrenoreceptor (AR), a member of the G-protein coupled receptor family, is the major subtype of $\beta A R$ in SM cells. Binding with $\beta_{2} A R$ agonists induces $\beta_{2} A R$ coupling with $\mathrm{G}_{\mathrm{s}}$ proteins, activation of adenylate cyclase and increase of cellular cAMP levels leading to parallel activation of protein kinase A (PKA) and Epac1 that synergize in mediating cAMP-dependent growth inhibition of VSM cells [7-11] suggesting that $\beta_{2} A R$ agonists may be considered as an attractive therapeutic approach to inhibit PAVSM cell proliferation in PH.

Formoterol is a long-acting $\beta_{2} \mathrm{AR}$ agonist that is commonly used as a bronchodilator to treat patients with COPD [12,13]. Formoterol is available in two formulations: racemic formoterol that consists of equal amounts of $(R, R)$ and $(S, S)$ enantiomers, and purified $(R, R)$ formoterol. (R,R) formoterol has 1000-times greater affinity to $\beta_{2} A R$ than $(S, S)$ enantiomer and shows improved bronchodilator effects compared to formoterol racemate [8]. Recent data demonstrate that, in addition to its function as a bronchodilator, racemic formoterol also acts as an anti-proliferative agent for airway smooth muscle cells [9] and human bronchial fibroblasts [14]. Currently, no information is available about the effects of formoterol in PAVSM cell proliferation as it relates to COPD-associated $\mathrm{PH}$, and comparative effects of racemic formoterol vs. its $(\mathrm{R}, \mathrm{R})$ and $(\mathrm{S}, \mathrm{S})$ enantiomers on PAVSM cell proliferation are also not examined.

The mechanisms by which formoterol regulates cell proliferation are not well understood. cAMP uptake regulates Raf1-extracellular signal-regulated kinases 1/2 (ERK1/2) cascade via PKA-specific direct phosphorylation of Raf1 or PKA- and Epac1-dependent Rap1 regulation [7,15-18]. cAMP is also shown to down-regulate protein tyrosine phosphorylation in VSM cells [19]. Studies from our laboratory and others demonstrate that ERK1/2 and mammalian target of rapamycin (mTOR), downstream effectors of receptor tyrosine kinases (RTK), are two major positive regulators of PAVSM cell proliferation induced by mitogens and chronic hypoxia [20-25]. ERK1/2 is required for PDGF-, insulin- and thrombin-induced proliferation of aortic and pulmonary arterial VSM cells [22,23]; and pharmacological inhibition of MEK-ERK1/2 signaling abolishes chronic hypoxia-induced rat PAVSM cell proliferation [24]. mTOR forms two functionally distinct complexes, mTORC1 and mTORC2 $[25,26]$. Chronic hypoxia, PDGF, and thrombin activate mTORC1 in PAVSM and endothelial cells that, in turn, stimulates cell growth via regulation of S6 kinase 1 (S6K1) and 4 EB-P1 [20-25]. The mTORC1 inhibitor rapamycin attenuates pulmonary vascular remodeling in experimental $\mathrm{PH}[27,28]$ and demonstrated benefits in treatment of patients with $\mathrm{PH}$ [29]. mTORC2 activates serine-threonine kinase Akt via specific phosphorylation at S-473 [30]. We recently reported that chronic hypoxia and PDGF activate mTORC2 signaling that is required for proliferation of human and rat PAVSM cells [25]. The effects of formoterol and its enantiomers on ERK1/2 and mTOR signaling pathways in PAVSM cells, however, remain to be elucidated.

The goal of this study was to evaluate the effects of racemic formoterol and its $(R, R)$ and $(S, S)$ enantiomers on proliferation of human PAVSM cells induced by PDGF, thrombin, and chronic hypoxia, recognized triggers of PAVSM cell proliferation and vascular remodeling in COPD-associated PH [31]. We found that formoterol inhibits basal, thrombin-, and chronic hypoxia-, but not PDGF-induced proliferation of human PAVSM cells and ERK1/2 phosphorylation while having little effect on mTOR signaling. We also show that the anti-proliferative effects of formoterol require its binding with $\beta_{2} A R$ and that $(\mathrm{R}, \mathrm{R})$ formoterol shows improved anti-proliferative effects compared to racemic formoterol. Taken together, our data demonstrate that formoterol inhibits human PAVSM cell proliferation caused by certain PH-related stimuli and suggest that $(R, R)$ formoterol may be considered as a potential adjuvant therapy to attenuate PAVSM cell proliferation in COPD-associated $\mathrm{PH}$.

\section{Methods}

\section{Cell culture}

Human PAVSM cells were dissociated from pulmonary arteries from failed donor lungs that were obtained from the National Disease Research Interchange (NDRI) (Philadelphia, PA), in accordance with procedures approved by the University of Pennsylvania Committee on Studies Involving Human Beings as previously described [20,25]. Briefly, a segment of human pulmonary artery just proximal to the lung entry was removed under aseptic conditions, cleaned from connective and fat tissues and dissected as follows: the media of pulmonary artery was dissected 
from the adventitia and intima and subjected to an enzymatic digestion in $10 \mathrm{ml}$ of buffer containing $0.2 \mathrm{mM} \mathrm{CaCl}_{2}$, $640 \mathrm{U} / \mathrm{ml}$ collagenase, $1 \mathrm{mg} / \mathrm{ml}$ soybean trypsin inhibitor and $10 \mathrm{U} / \mathrm{ml}$ elastase for approximately $60 \mathrm{~min}$ in a shaking water bath at $37^{\circ} \mathrm{C}$. The cell suspension was filtered through $105 \mu \mathrm{m}$ Nytex mesh, and the filtrate was washed with equal volumes of cold Ham's F-12 medium (Life Technologies, Grand Island, NY) supplemented with 10\% FBS (HyClone, Logan, UT). Cells were plated on tissue culture plates covered with Vitrogen (Cohesion Technologies Inc., Palo Alto, CA). Cells were cultured in Ham's F-12 media supplemented with 10\% FBS (Becton Dickinson, Bedford, MA), $100 \mathrm{U} / \mathrm{ml}$ penicillin, and $0.1 \mathrm{mg} / \mathrm{ml}$ streptomycin.

For chronic hypoxia experiments, cells were maintained either in normoxic $\left(21 \% \mathrm{O}_{2}, 5 \% \mathrm{CO}_{2}\right)$ or in hypoxic $\left(1 \% \mathrm{O}_{2}, 5 \% \mathrm{CO}_{2}\right)$ conditions for 7 days in complete media and then for $48 \mathrm{~h}$ in serum-free media supplemented with $0.1 \%$ BSA. $1 \% \mathrm{O}_{2}$ was used as we described [25] to reproduce the tissue oxygen levels of moderate chronic hypoxia [32,33] based on data obtained from the rat chronic hypoxia model of $\mathrm{PH}[34,35]$. To avoid re-oxygenation, fresh complete or serum-free media was pre-equilibrated at $1 \% \mathrm{O}_{2}$, before adding to PAVSM cells grown under hypoxia. Primary human PAVSM cells in subculture during the second through tenth cell passages were used. All experiments were performed using a minimum of three different cell cultures. Each human PAVSM cell culture was established using pulmonary arterial tissue from a single human donor.

\section{DNA synthesis analysis}

Cells grown under normoxia or chronic hypoxia were serum deprived for $48 \mathrm{~h}$, treated with $0.1,1$, or $10 \mathrm{ng} / \mathrm{ml}$ PDGF-BB, $1 \mathrm{U} / \mathrm{ml}$ thrombin, 0.2 , 2, or $20 \mu \mathrm{M}$ racemic, $(\mathrm{R}, \mathrm{R})$, or $(\mathrm{S}, \mathrm{S})$ formoterol, or diluent for $18 \mathrm{~h}$ followed by DNA synthesis analysis using the BrdU incorporation assays as we described [25,36-38]. Briefly, cells were incubated with $10 \mu \mathrm{M}$ BrdU for $24 \mathrm{~h}$, fixed with $3.7 \%$ paraformaldehyde (Polysciences, Inc., Warrington, PA) for $15 \mathrm{~min}$ and permeabilized with $0.1 \%$ Triton X-100 for $30 \mathrm{~min}$ at room temperature. Following denaturation of DNA with $4 \mathrm{~N} \mathrm{HCl} \mathrm{(3} \mathrm{min}$ at room temperature), incubated for $1 \mathrm{~h}$ at $37^{\circ} \mathrm{C}$ with $2 \mu \mathrm{g} / \mathrm{ml}$ murine antiBrdU primary (Becton Dickinson, San Jose, CA) and $10 \mu \mathrm{g} / \mathrm{ml}$ Texas Red-conjugated anti-mouse secondary (Jackson ImmunoResearch Laboratories, West Grove, PA) antibodies for $1 \mathrm{~h}$ at $37^{\circ} \mathrm{C}$ to detect BrdU-positive cells. To detect the total number of nuclei, cells were incubated with $1 \mu \mathrm{g} / \mathrm{ml}$ DAPI. Then, cells were visualized using Eclipse Nikon TE2000E fluorescent microscope (200x magnification), and automatic counts of BrdU-positive and total number of cells were performed using Image-Pro Plus 5.1 software.

\section{Immunoblot analysis}

Whole cell lysates were prepared using a buffer comprised of $40 \mathrm{mM}$ HEPES (pH 7.5), $120 \mathrm{mM} \mathrm{NaCl}, 1 \mathrm{mM}$ EDTA, $10 \mathrm{mM}$ sodium pyrophosphate $\left(\mathrm{Na}_{4} \mathrm{P}_{2} \mathrm{O}_{7} \mathrm{x}\right.$ $\left.10 \mathrm{H}_{2} \mathrm{O}\right), 10 \mathrm{mM}$-glycerophosphate, $50 \mathrm{mM} \mathrm{NaF}$, $1.5 \mathrm{mM} \mathrm{Na}_{3} \mathrm{VO}_{4}, 1 \%$ Triton X-100, EDTA-free inhibitor cocktail. Protein contents were measured using a BioRad protein assay reagent kit. Equal amounts of lysate, adjusted for protein content, were subjected to SDS-PAGE and then immunoblot analysis. The blots were exposed to anti-phospho-S6 ribosomal protein, anti-total S6, antiphospho Akt Ser-473, anti-total Akt, anti-phospho ERK, anti-total ERK, anti-phospho S6K1 T-389, and anti-total S6K1 antibodies (Cell Signaling Technology, Inc., Beverly, MA). All antibodies were in $20 \mathrm{mM}$ Tris ( $\mathrm{pH} 7.5$ ), $150 \mathrm{mM} \mathrm{NaCl}$ (TBS) plus 0.5\% Tween 20 (TBST), and all incubations were for overnight at $4^{\circ} \mathrm{C}$. After 3 washes in TBST, the nitrocellulose membranes were exposed to horseradish peroxidase-conjugated secondary antibody (Boehringer-Mannheim, Indianapolis, IN), washed five times in TBST and visualized using enhanced chemiluminescence (ECL) (Amersham, Arlington Heights, IL).

\section{Data analysis}

Data points from each condition are represented as the mean values $\pm \mathrm{SE}$. Three independent repetitions were performed for each experimental condition. Statistical analysis was performed using StatView software. Statistically significant differences among groups were assessed with the analysis of variance (ANOVA) (Bonferroni-Dunn) with values of $p<0.05$ sufficient to reject the null hypothesis for all analyses. All experiments were designed with matched control conditions within each experiment to enable statistical comparison as paired samples.

\section{Results}

\section{Formoterol inhibits basal and thrombin-, but not} PDGF-induced human PAVSM cell proliferation

Because formoterol inhibits proliferation of human bronchus fibroblasts and airway smooth muscle cells $[9,14]$, we examined the effects of formoterol and its enantiomers on the proliferation of human PAVSM cells under serumdepleted conditions and in the presence of thrombin and PDGF, confirmed PAVSM mitogens that are involved in $\mathrm{PH}$ pathogenesis $[20,39,40]$. Consistent with our published data [20], serum-deprived PAVSM cells had modest levels of DNA synthesis that were significantly increased by treatment with PDGF and thrombin (Figure 1A). Racemic formoterol inhibited DNA synthesis in serum-deprived human PAVSM cells in a concentration-dependent manner (Figure $1 B)$. (R,R) formoterol had a greater inhibitory effect on human PAVSM cell proliferation compared to racemic formoterol $\left(\mathrm{IC}_{50} \sim 1 \mu \mathrm{M}\right.$ and $\sim 4 \mu \mathrm{M}$, respectively). (S,S)formoterol had modest inhibitory effect $\left(\mathrm{IC}_{50} \sim 20 \mu \mathrm{M}\right)$ 

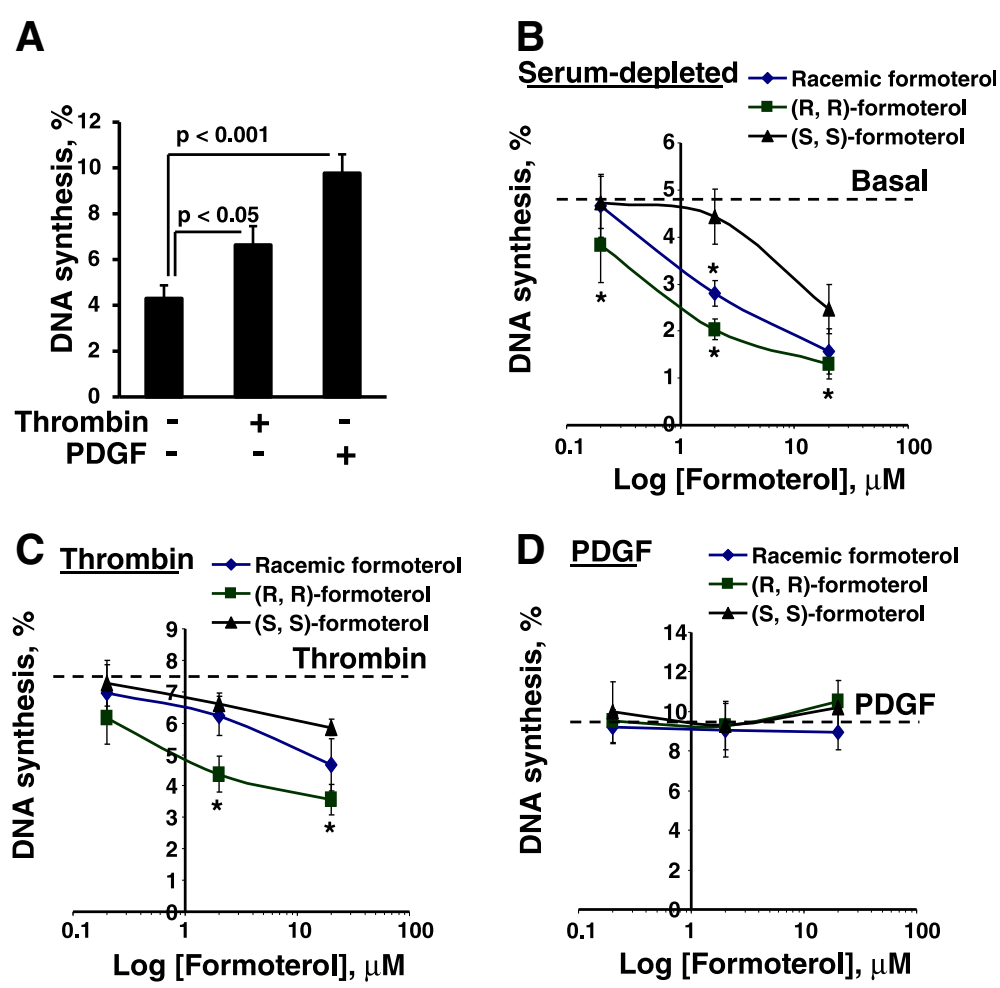

Figure 1 Formoterol inhibits basal and thrombin-, but not PDGF-induced DNA synthesis in human PAVSM cells. A: Cells serum-deprived for $48 \mathrm{~h}$ were treated for $18 \mathrm{~h}$ with $1 \mathrm{U} / \mathrm{ml}$ thrombin, $10 \mathrm{ng} / \mathrm{ml} \mathrm{PDGF}$, or diluent followed by DNA synthesis analysis using the BrdU incorporation assay. Data represent a percentage of BrdU-positive cells per total number of cells taken as 100\%. Data are mean values \pm SE from three independent experiments. A minimum of 200 cells per each condition were analyzed in each experiment. B-D: Cells serum-deprived for $48 \mathrm{~h}$ were treated with 0.2, 2, $20 \mu \mathrm{M}(\mathrm{R}, \mathrm{R})$-, $(\mathrm{S}, \mathrm{S})$-, racemic formoterol, or diluent in the presence of vehicle (B), $1 \mathrm{U} / \mathrm{ml}$ thrombin $(\mathbf{C})$ or $10 \mathrm{ng} / \mathrm{ml}$ PDGF (D) followed by DNA synthesis analysis using the BrdU incorporation assay. Data are means \pm SE from three separate experiments, $n=3$ for each experimental condition. ${ }^{*} p<0.001$ for formoterol vs. diluent and for thrombin $+(R, R)$ formoterol vs. thrombin by ANOVA (Bonferroni-Dunn). A minimum of 200 cells per condition were analyzed in each experiment.

and attenuated DNA synthesis only when used in maximal dose. (R,R) and, to a lesser extent, racemic formoterol significantly inhibited thrombin-induced human PAVSM cell proliferation $\left(\mathrm{IC}_{50}\right.$ for $(\mathrm{R}, \mathrm{R})$ formoterol $\left.\sim 20 \mu \mathrm{M}\right)$, and $(\mathrm{S}, \mathrm{S})$ formoterol had no significant effect (Figure 1C). Both racemic and (S,S) formoterol did not provide 50\% inhibition of cell proliferation even when administrated in high doses $(20 \mu \mathrm{M})$. Interestingly, racemic formoterol and both formoterol enantiomers had no effect on PDGF-induced proliferation of human PAVSM cells (Figure 1D). These data demonstrate that formoterol inhibits basal and thrombin-induced, but not PDGF-stimulated human PAVSM cell proliferation and suggest that growth inhibitory effects of formoterol depend predominantly on its $(R, R)$, but not $(\mathrm{S}, \mathrm{S})$ enantiomer.

\section{Formoterol inhibits PAVSM cell proliferation caused by chronic hypoxia exposure}

Because chronic hypoxia is one of the confirmed triggers of PAVSM cell proliferation and pulmonary vascular remodeling in $\mathrm{PH}[2,41]$, we next examined whether formoterol modulates chronic hypoxia-induced PAVSM cell proliferation. As we demonstrated previously [25], chronic hypoxia increased basal and PDGF-induced human PAVSM cell proliferation compared to normoxiamaintained cells (Figure 2A and B, respectively). Importantly, (R,R)-formoterol inhibited chronic hypoxia-induced PAVSM cell proliferation by the level comparable to normoxia-maintained cells, racemic formoterol had lesser inhibitory effect, and no significant differences in cell proliferation were observed in $(\mathrm{S}, \mathrm{S})$ formoterol- vs. diluenttreated PAVSMC under chronic hypoxia (Figure 2A). Interestingly, $10 \mu \mathrm{M}(\mathrm{R}, \mathrm{R})$ and racemic formoterol attenuated PAVSM cell proliferation in the presence of $0.1 \mathrm{ng} / \mathrm{ml}$ PDGF, but had little effect on the proliferation induced by higher PDGF doses (1 and $10 \mathrm{ng} / \mathrm{ml}$ ) either under chronic hypoxia or normoxia (Figure 2B) demonstrating that PDGF-induced PAVSM cell proliferation is not susceptible to formoterol. Taken together, these data demonstrate that formoterol attenuates basal, but not PDGF-induced human PAVSM proliferation under chronic hypoxia and that formoterol acts predominantly through its $(R, R)$ enantiomer. 

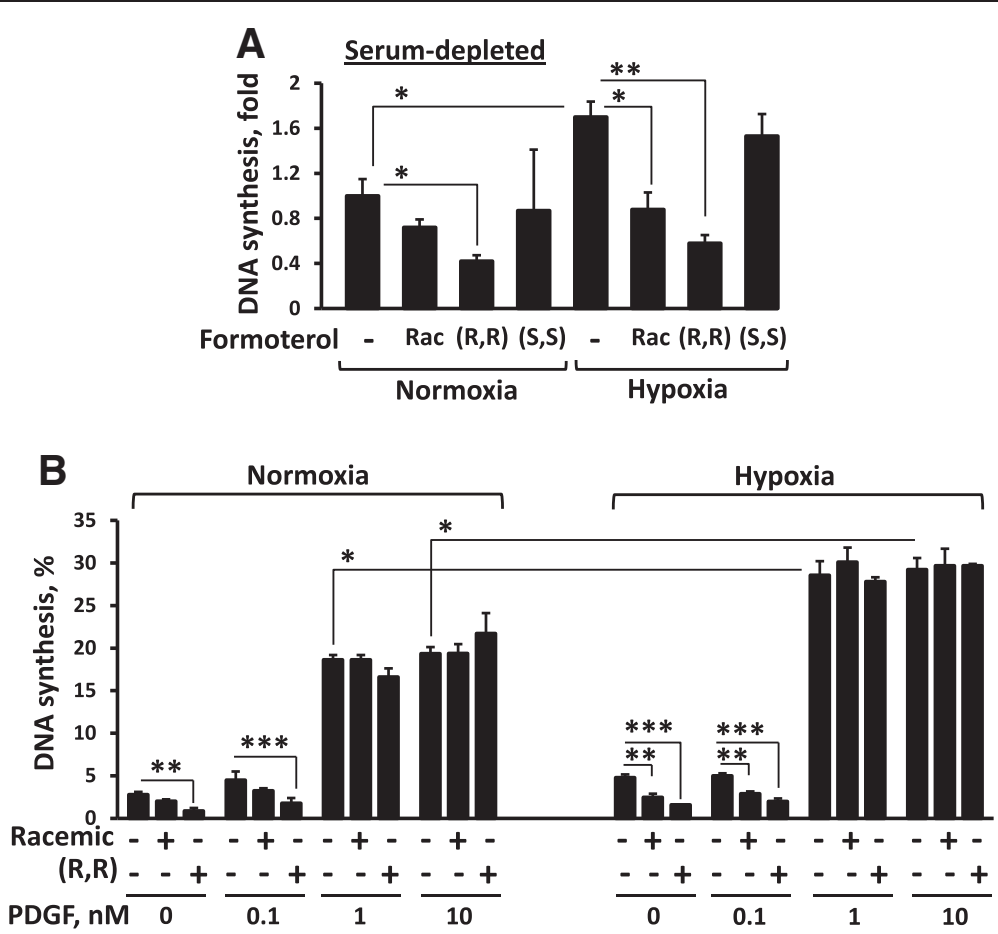

Figure 2 Formoterol inhibits chronic hypoxia-induced human PAVSM cell proliferation. Cells grown under chronic hypoxia (1\% $\left.\mathrm{O}_{2}\right)$ or normoxia $\left(21 \% \mathrm{O}_{2}\right)$ for 7 days were serum-deprived for $48 \mathrm{~h}$, treated with $10 \mu \mathrm{M}(\mathrm{R}, \mathrm{R})$-, $(\mathrm{S}, \mathrm{S})$-, racemic formoterol, or diluent $(\mathrm{A})$, or $0.1,1,10 \mathrm{ng} / \mathrm{ml}$ PDGF, or diluent in the absence or presence of $10 \mu \mathrm{M}(\mathrm{R}, \mathrm{R})$ and racemic formoterol $(\mathrm{B})$, and then DNA synthesis analysis using the BrdU incorporation assay was performed. DNA synthesis was measured as a percentage of the BrdU-positive cells per total number of cells. Data are means \pm SE by ANOVA (Bonferroni-Dunn) from three independent experiments; $n=3$ for each experimental condition. A minimum of 200 cells per condition were analyzed in each experiment. A: ${ }^{*} p<0.01$ for diluent-treated cells under normoxia vs. hypoxia and for racemic formoterol vs. $(R, R)$ formoterol under normoxia; ${ }^{* *} p<0.001$ for racemic formoterol vs. $(R, R)$ formoterol under hypoxia. B: ${ }^{*} p<0.001$ for hypoxia vs. normoxia; ${ }^{* *} \mathrm{p}<0.01$ for diluent vs. (R,R) formoterol under normoxia; for diluent vs. racemic formoterol under hypoxia; and for $0.1 \mathrm{ng} / \mathrm{ml}$ PDGF vs. $0.1 \mathrm{ng} / \mathrm{ml}$ PDGF + racemic formoterol under hypoxia; ${ }^{* * *} \mathrm{p}<0.001$ for $0.1 \mathrm{ng} / \mathrm{ml}$ PDGF vs. $0.1 \mathrm{ng} / \mathrm{ml}$ PDGF + (R,R) formoterol under normoxia; for diluent vs. $(R, R)$ formoterol under hypoxia; and for $0.1 \mathrm{ng} / \mathrm{ml}$ PDGF + (R,R) formoterol under hypoxia.

\section{Binding with $\beta_{2} A R$ is required for formoterol-induced} inhibition of human PAVSM cell proliferation

Since the bronchodilatory functions of formoterol require binding of its $(R, R)$ enantiomer with specific $\beta_{2} A R$ [42], we next examined whether binding with $\beta_{2} A R$ contributes to anti-proliferative effects of formoterol in human PAVSM cells. Serum-deprived cells were treated with the $\beta_{2}$ AR blocker propranolol in the presence of $0.2-20 \mu \mathrm{M}$ of $(\mathrm{R}, \mathrm{R}),(\mathrm{S}, \mathrm{S})$ and racemic formoterol, or diluent and then subjected to DNA synthesis analysis using the BrdU incorporation assay. As seen in Figure 3 (grey bars), (R,R), racemic, and, to a lesser extent, $(\mathrm{S}, \mathrm{S})$-formoterol inhibited DNA synthesis in human PAVSM cells depending on agent concentration. Importantly, propranolol completely reversed inhibitory effects of racemic, $(R, R)$-, and $(S, S)$ formoterol on PAVSM cell proliferation (Figure 3, black bars). These data demonstrate that binding with $\beta_{2} A R$ is required for formoterol-dependent inhibition of human PAVSM cell proliferation.
$(\mathrm{R}, \mathrm{R})$ formoterol inhibits basal and thrombin-, but not PDGFinduced ERK1/2 phosphorylation in human PAVSM cells Because ERK1/2 signaling is involved in human PAVSM cell proliferation, we next determined the effects of formoterol and its enantiomers on ERK1/2 activatory phosphorylation. As seen in Figure 4A, $(R, R)$ and, to a lesser extent, racemic, but not $(S, S)$ formoterol inhibited basal ERK1/2 phosphorylation. Because PDGF and thrombin, but not chronic hypoxia, markedly activate ERK1/2 in PAVSM cells $[20,25,43,44]$ (Figure 4B), ERK1/2 activation and since $(R, R)$ formoterol demonstrated maximal inhibitory effects on human PAVSM cell proliferation and basal ERK1/2 phosphorylation compared to racemic and $(S, S)$ formoterol, we next evaluated effects of $(R, R)$ formoterol on ERK1/2 phosphorylation induced by PDGF and thrombin. As seen in Figure 4C, D, (R,R) formoterol abrogated thrombin-induced ERK1/2 phosphorylation while having little effect on ERK1/2 phosphorylation induced by PDGF over a range of concentrations $(0.1-10 \mathrm{ng} / \mathrm{ml})$. Similarly, 


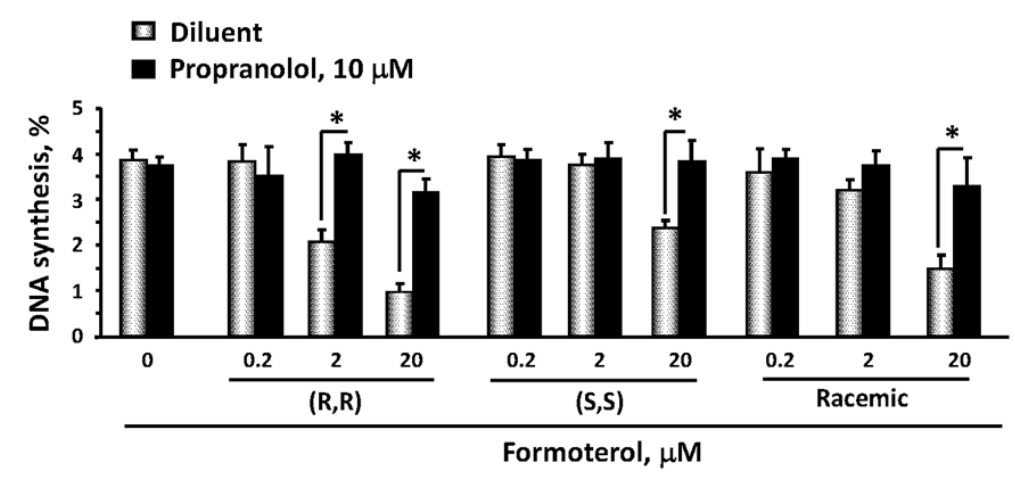

Figure $3 \beta_{2}$ AR blocker propranolol abolishes formoterol-induced inhibition of DNA synthesis in human PAVSM cells. Cells were serum-deprived for $48 \mathrm{~h}$, treated with 0.2, 2, $20 \mathrm{mM}(\mathrm{R}, \mathrm{R}),(\mathrm{S}, \mathrm{S})$, racemic formoterol, or diluent for $18 \mathrm{~h}$ in the presence (black bars) or absence (grey bars) of $10 \mu \mathrm{M}$ propranolol followed by DNA synthesis analysis using the BrdU incorporation assay. Data represent mean values \pm SE from two independent experiments, three repetitions per each experiment. ${ }^{*} \mathrm{p}<0.001$ for formoterol vs. formoterol + propranolol by ANOVA (Bonferroni-Dunn).

both $(\mathrm{R}, \mathrm{R})$ and racemic formoterol failed to inhibit PDGFinduced ERK1/2 phosphorylation either under normoxia or chronic hypoxia conditions (data not shown). Taken together, these data demonstrate that racemic and $(R, R)$ formoterol down-regulate basal and thrombin-induced, but not PDGF-dependent ERK1/2 phosphorylation in human PAVSM cells.

\section{Formoterol has no effect on mTOR signaling in human PAVSM cells}

Next, we examined whether formoterol modulates mTOR signaling in human PAVSM cells by assessing mTORC1specific ribosomal protein $\mathrm{S} 6$ and mTORC2-specific S473Akt phosphorylation. Consistent with our published data $[20,25]$, serum-deprived human PAVSM cells had modest S6 phosphorylation levels that were markedly increased by thrombin and PDGF (Figure 5A). In contrast, PDGF, but not thrombin, promoted S473-Akt phosphorylation (Figure 5A) suggesting that both PDGF and thrombin activate mTORC1 signaling in human PAVSM cells while only PDGF increases mTORC2 activity. As we reported previously [25], exposure to chronic hypoxia led to a marked increase in mTORC1-dependent P-S6K1 and P-S6 and mTORC2-dependent P-S473-Akt (Figure 5B) demonstrating that chronic hypoxia activates both $\mathrm{mTORC} 1$ and mTORC2 pathways in human PAVSM cells. Interestingly, racemic formoterol and both $(\mathrm{R}, \mathrm{R})$ and $(\mathrm{S}, \mathrm{S})$ formoterol enantiomers had no effect on basal, PDGF- and thrombininduced S6 phosphorylation either under normoxia or chronic hypoxia (Figure 5C). PDGF-induced S473-Akt phosphorylation was also comparable in diluent-, (R,R)-, (S,S)-, and racemic formoterol-treated cells (Figure 5D). Collectively, these data demonstrate that formoterol has little effect on mTORC1 and mTORC2 signaling pathways in human PAVSM cells.

\section{Discussion}

$\mathrm{PH}$ is a progressive disease with poor prognosis, the pathological manifestations of which include vasoconstriction and pulmonary vascular remodeling [5,45]. PH may be familial, idiopathic, or associated with other diseases. Notably, patients with COPD-associated $\mathrm{PH}$ have higher morbidity and reduced survival compared to other COPD patients $[3,4]$. Pulmonary vascular remodeling in $\mathrm{PH}$ is associated with marked medial thickening of small muscular PAs due, at least in part, to increased proliferation of PAVSM cells. PAVSM cell proliferation in COPD-associated PH is caused by multiple factors including persistent hypoxia and increased production of growth factors and pro-inflammatory cytokines $[2,31,46]$. Our study demonstrates that $\beta_{2} \mathrm{AR}$ agonist formoterol inhibits proliferation of PAVSM cells induced by thrombin and chronic hypoxia, but not PDGF. Anti-proliferative activity of formoterol requires binding with $\beta_{2} A R$, and $(R, R)$ enantiomer of formoterol shows improved anti-growth effects compared to racemic and $(\mathrm{S}, \mathrm{S})$ formoterol. We also report that formoterol inhibits basal and thrombin-induced activation of ERK1/2, but has no effect on mTOR signaling in human PAVSM cells.

Deregulated PAVSM cell proliferation is one of the major pathological components of pulmonary vascular remodeling in $\mathrm{PH}$. The long-term $\beta_{2} \mathrm{AR}$ agonist formoterol, which is currently in use as bronchodilator in COPD, shows anti-proliferative activities in human airway smooth muscle cells and bronchus fibroblasts $[9,14]$. In the present study, we explored effects of formoterol on human PAVSM cell proliferation caused by different stimuli involved in $\mathrm{PH}$ pathogenesis $[2,31,47]$ and found that the growth-inhibitory potency of formoterol highly depends on extracellular stimuli. Thus, formoterol and, especially, its $(R, R)$ enantiomer, inhibited proliferation of nonstimulated PAVSM cells under chronic hypoxia, decreased 
A
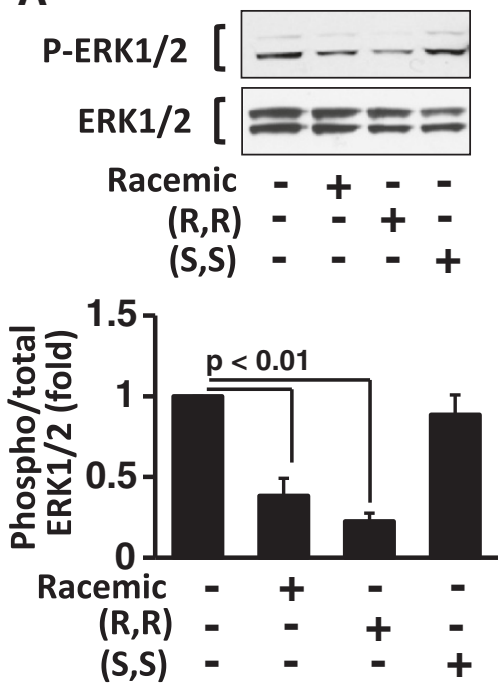

C

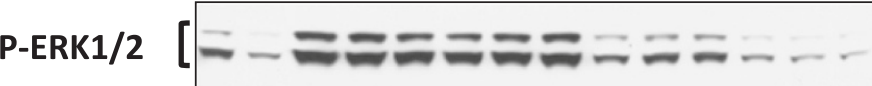

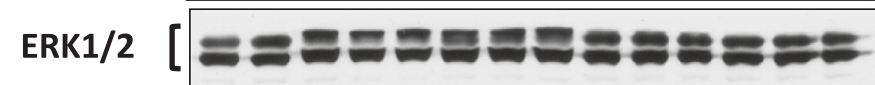

PDGF, ng/ml - - 0.11100 .1110 - - - - - -

Thrombin, U/ml - - - - - - - - 0.10 .510 .10 .51

$(\mathrm{R}, \mathrm{R})$-formoterol $-+-\cdot+++-\cdot+++$

D

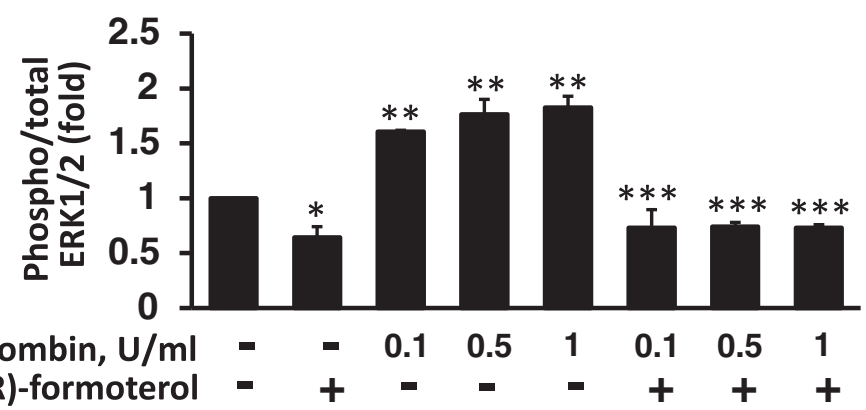

Figure 4 Differential effects of formoterol on basal, thrombin- and PDGF-induced ERK1/2 phosphorylation in human PAVSM cells. A: $(R, R)$ and racemic, but not $(S, S)$ formoterol inhibit ERK1/2 phosphorylation in human PAVSM cells. Cells serum-deprived for $48 \mathrm{~h}$ were treated with $10 \mu \mathrm{M}(\mathrm{R}, \mathrm{R}),(\mathrm{S}, \mathrm{S})$, racemic formoterol or diluent for $30 \mathrm{~min}$ followed by immunoblot analysis with anti-phospho ERK1/2 and anti-total ERK1/2 antibodies. Top panel: Images are representative of three independent experiments. Bottom panel: Statistical analysis of three separate experiments, $\mathrm{n}=3$ for each experimental condition. Data represent mean values \pm SE by ANOVA (Bonferroni-Dunn). Phospho-ERK/total ERK ratio for diluent-treated cells was taken as one fold. B: Cells serum-deprived for $48 \mathrm{~h}$ were treated with $1 \mathrm{U} / \mathrm{ml}$ thrombin, $10 \mathrm{ng} / \mathrm{ml} \mathrm{PDGF,} \mathrm{or} \mathrm{diluent}$ for $30 \mathrm{~min}$ followed by immunoblot analysis with anti-phospho ERK1/2 and anti-total ERK1/2 antibodies. Top panel: Representative images from three independent experiments. Bottom panel: Statistical analysis of three independent experiments; $n=3$ for each experimental condition. Data are mean values \pm SE by ANOVA (Bonferroni-Dunn). Phospho-ERK/total ERK ratio for diluent-treated cells was taken as one fold. C, D: (R,R) formoterol inhibits thrombin-, but not PDGF-induced ERK1/2 phosphorylation in human PAVSM cells. Cells were serum-deprived for $48 \mathrm{~h}$, incubated for 30 min with $10 \mu \mathrm{M}(\mathrm{R}, \mathrm{R}),(\mathrm{S}, \mathrm{S})$, or racemic formoterol in the presence or absence of $10 \mathrm{ng} / \mathrm{ml}$ PDGF, and then immunoblot analysis with anti-phospho-ERK1/2 and anti-total ERK1/2 antibodies was performed. C: Representative images. D: Statistical analysis of three separate experiments. Data are mean \pm SE by ANOVA (Bonferroni-Dunn). Phospho/total ERK ratio for diluent-treated cells was taken as one fold. ${ }^{*} \mathrm{p}<0.05$ for diluent vs. $(\mathrm{R}, \mathrm{R})$ formoterol; ${ }^{* *} \mathrm{p}<0.01$ for diluent vs. thrombin; ${ }^{* * *} \mathrm{p}<0.01$ for thrombin vs. thrombin $+(\mathrm{R}, \mathrm{R})$ formoterol. 


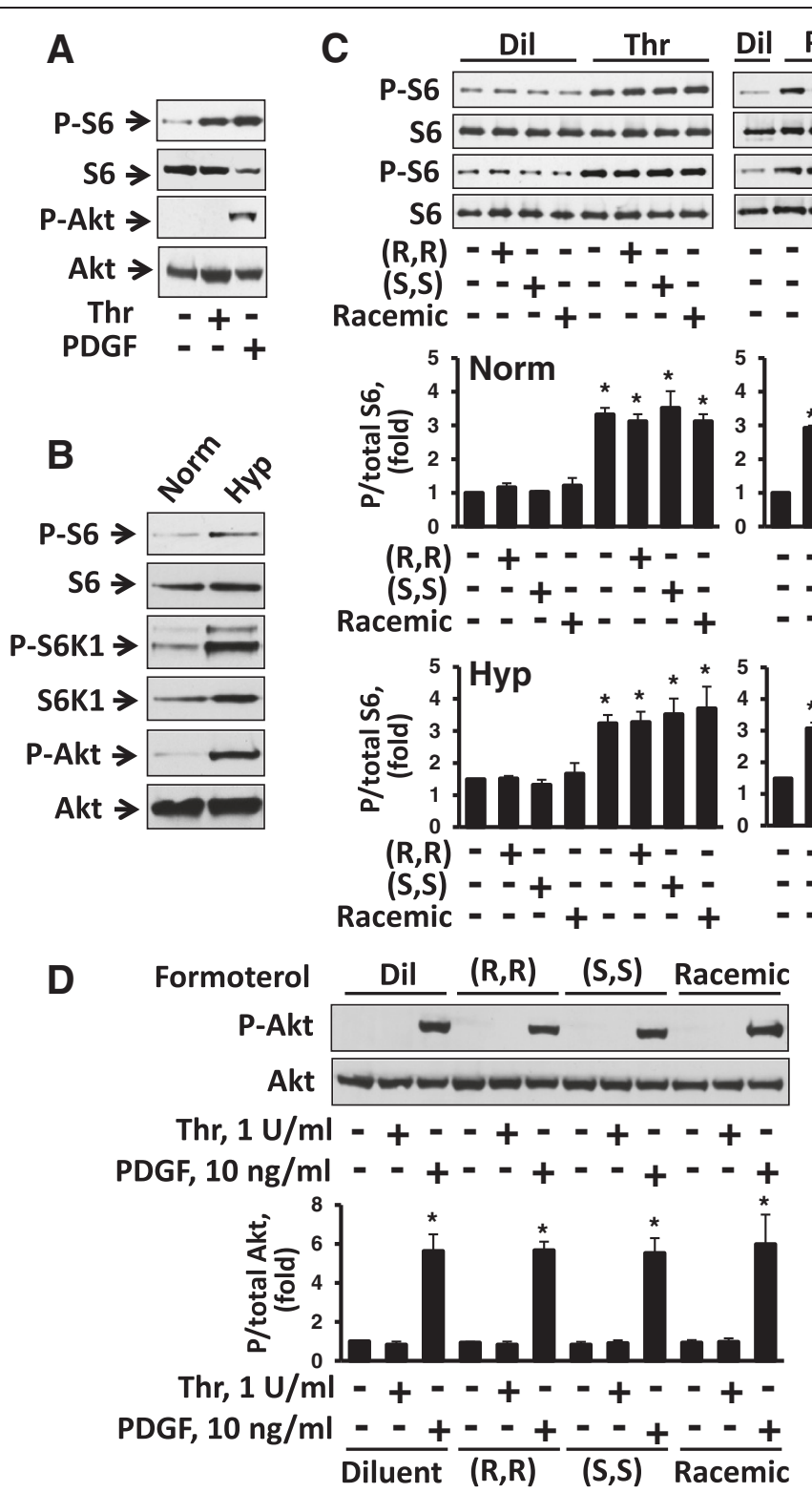

Figure 5 Formoterol does not affect mTORC1 and mTORC2 activation by chronic hypoxia, thrombin and PDGF. A: Human PAVSM cells serum-deprived for $48 \mathrm{~h}$ were treated with $1 \mathrm{U} / \mathrm{ml}$ thrombin (thr), $10 \mathrm{ng} / \mathrm{ml} \mathrm{PDGF}$, or diluent (dil) for $30 \mathrm{~min}$, and then immunoblot analysis with anti-phospho S6, anti-total S6, anti-phospho S473-Akt, and anti-total Akt was performed. Images are representative of three independent experiments. B: Chronic hypoxia promotes S6, S6K1, and S473-Akt phosphorylation in human PAVSM cells. Human PAVSM cells serum-deprived for $48 \mathrm{~h}$ maintained under chronic hypoxia (hyp) or normoxia (norm) were subjected to immunoblot analysis with specific antibodies to detect indicated proteins. Images are representative of three independent experiments. C, D: Formoterol has no effect on S6 and S473-Akt phosphorylation. C: Serum-deprived cells maintained under hypoxia or normoxia were incubated for 30 min with $10 \mu M(R, R)-$, $(S, S)$, or racemic formoterol, treated with different concentrations of thrombin and PDGF, or diluent, and then immunoblot analysis with anti-phospho-S6 and anti-total $\mathrm{S} 6$ antibodies was performed. Representative images (top) and statistical analysis (bottom) of three independent experiments. Data represent P/total $\mathrm{S} 6$ ratio ( $n=3$ for each experimental condition). P/total $\mathrm{S} 6$ ratio for diluent-treated normoxia-exposed cells was taken as one fold). Data are means \pm SE by ANOVA (Bonferroni-Dunn). ${ }^{*} p<0.001$ for thrombin vs. diluent, thrombin $+(R, R),(S, S)$ and racemic formoterol vs. $(\mathrm{R}, \mathrm{R}),(\mathrm{S}, \mathrm{S})$ and racemic formoterol, respectively. D: Immunoblot analysis of serum-deprived normoxia-maintained cells treated as described above was performed to detect P-S473-Akt and total Akt levels. Representative images (top) and data analysis (bottom) from three separate experiments. Data represent P-S473/total Akt ratio ( $n=3$ for each experimental condition) normalized by P/total Akt for diluent-treated cells (taken as one fold). Data are means $\pm \mathrm{SE}$ by ANOVA (Bonferroni-Dunn). ${ }^{*} \mathrm{p}<0.001$ for PDGF vs. diluent, PDGF $+(R, R)$ formoterol vs. (R,R) formoterol, PDGF + $(\mathrm{S}, \mathrm{S})$ formoterol vs. $(\mathrm{S}, \mathrm{S})$ formoterol, and PDGF + racemic formoterol vs. racemic formoterol. 
thrombin-induced proliferation, but had no significant effect on PDGF-dependent PAVSM cell growth.

The mechanisms of $\beta_{2} \mathrm{AR}$-dependent regulation of cell proliferation are relatively unexplored and appear to be highly cell type-specific. $\beta_{2}$ AR-induced PKA activation, while inhibiting proliferation in the majority of cell types including vascular smooth muscle cells $[8-11,48,49]$ stimulates proliferation of human uveal melanoma cells [50] and cardiomyocyte hypertrophy [51]. Activation of $\beta_{2}$ ARcAMP signaling also up-regulates Epac1, the predominant Epac isoform in VSM cells [7]. Epac1 synergizes with PKA in inhibiting VSM cell proliferation [7], but increases DNA synthesis in macrophages and prostate cancer cells $[52,53]$. Our data show that formoterol-dependent inhibition of human PAVSM cells requires its binding with $\beta_{2}$ AR. Accordingly, $(R, R)$ formoterol, which has much higher receptor affinity and greater potency to induce $\beta_{2}$ AR- $G_{s}$-dependent cAMP production and PKA activation compared to $(\mathrm{S}, \mathrm{S})$ formoterol $[8,54]$, demonstrates greater anti-proliferative effects than formoterol racemate while $(\mathrm{S}, \mathrm{S})$ formoterol has modest effects on PAVSM cell proliferation.

Emerging evidence shows that, in addition to classical $G_{s}$-cAMP pathway, $\beta_{2} A R$ may interact with $G_{i}$ proteins that, in contrast to $G_{s}$, leads to reduction of cAMP levels and inhibition of PKA-dependent signaling [55]. Currently, no evidence exists about involvement of $G_{i}$ in PAVSM cell proliferation and pulmonary vascular remodeling in $\mathrm{PH}$. In contrast, $\mathrm{G}_{\mathrm{s}}$-dependent activation of cAMP-PKA signaling is well documented in human ASM and PAVSM cells upon formoterol treatment and is required for bronchodilatory and vasodilatory effects of formoterol on COPD patients and for inhibition of SM cell proliferation [7-11,56]. $G_{i}$ overexpression, however, has been reported in heart and aorta of spontaneously hypertensive rats; and $G_{i}$ suppression with pertussis toxin attenuated development of high blood pressure in this model [55,57-59] suggesting differential mechanisms of $\beta_{2} A R$ signaling in heart vs. pulmonary vasculature.

The signaling pathways underlying formoterol-dependent inhibition of cell proliferation are not well evaluated. We and others previously demonstrated that thrombin promotes human PAVSM cell proliferation via ERK1/2 signaling while PDGF acts via activation of two major proproliferative pathways, PI3K-mTOR and MEK-ERK1/2 [60]. In the majority of cells, including VSM, cAMPdependent activation of PKA and Epac inhibits ERK1/2 signaling via modulating activities of small GTPases Raf- 1 and Rap-1 downstream of Ras $[15,61,62]$ clearly demonstrating functional cross-talk between ERK1/2 and $\beta_{2}$ ARcAMP cascades.

Interestingly, we found that formoterol markedly inhibits thrombin-, but not PDGF-induced ERK1/2 phosphorylation. A possible explanation is that PDGF, in addition to ERK1/2, also promotes strong up-regulation of PI3K signaling $[20,25]$, and we found that PI3K is insensitive to formoterol. PI3K stimulates ERK1/2 activation via Raf- 1 and Rap-1 in a Ras-independent manner $[63,64]$ and can counter-balance formoterol- $\beta_{2}$ ARcAMP-dependent ERK1/2 inhibition. Indeed, our data show that formoterol markedly inhibits ERK1/2 phosphorylation in chronic hypoxia-exposed PAVSM cells, in which mTOR activation and proliferation occur in a PI3K-independent manner [25].

Chronic hypoxia-induced proliferation of PAVSM cells requires expression of hypoxia-inducible factor $1 \alpha$ (HIF $1 \alpha)$, which plays a critical role in PAVSM remodeling in human and experimental PH [31,65]. Notably, ERK1/2 upregulates HIF1 $\alpha$ transcriptional activity via direct phosphorylation that promotes HIF $1 \alpha$ nuclear translocation or via regulating binding of HIF1 $\alpha$ with its major co-activator p300/cAMP response element-binding protein (CBP) [6669]. Thus, formoterol may inhibit chronic hypoxia-induced PAVSM cell proliferation via down-regulation of ERK1/2dependent HIF1 $\alpha$ transcriptional activity.

Although much less is known about the regulation of the mTOR signaling pathway by cAMP/PKA, it is shown that cAMP elevation inhibits mTORC1/S6K1 in T lymphocytes [70], but not in CCL39 fibroblasts [71] suggesting that effects of cAMP/PKA on mTOR activation are cell type-specific. Our data show that formoterol has no effect on activation of mTORC1 and mTORC2 signaling pathways caused by either PDGF or chronic hypoxia. These data indicate that mitogen- and chronic hypoxiainduced mTOR activation in human PAVSM cells is $\beta_{2} \mathrm{AR}$-independent.

Taken together, our study demonstrates that formoterol inhibits basal, chronic hypoxia- and thrombin-, but not PDGF-induced human PAVSM cell proliferation potentially via $\beta_{2} A R$-dependent inhibition of ERK $1 / 2$ signaling pathway; and that anti-proliferative activity of formoterol is provided predominantly by its $(R, R)$ enantiomer. This data suggests that $(R, R)$ formoterol, while having a limited effect as a single agent, may be considered as a potential adjuvant therapy for COPD-associated $\mathrm{PH}$.

\section{Conclusions}

Collectively, our data demonstrate that the $\beta_{2} \mathrm{AR}$ agonist formoterol inhibits basal, thrombin-, and chronic hypoxiainduced ERK1/2 activation and proliferation of human PAVSM cells, but has little effect on PDGF-induced ERK1/2 activation, proliferation and mTOR signaling. We also show that formoterol acts predominantly through its $(\mathrm{R}, \mathrm{R})$ enantiomer and that anti-proliferative effects of formoterol require $\beta_{2} A R$ binding. These data suggest that $(\mathrm{R}, \mathrm{R})$ formoterol inhibits human PAVSM cell proliferation in certain conditions and may be considered as a potential adjuvant therapy for COPD-associated PH. 


\section{Abbreviations}

ANOVA: Analysis of variance; $\beta_{2} A R$ : $\beta_{2}$-adrenergic receptor; $B r d U$ : 5-bromo-2'-deoxyuridine; COPD: Chronic obstructive pulmonary disease; DAPI: 4',6-diamidino-2-phenylindole; ERK1/2: Extracellular signal-regulated kinases 1/2; HIF1a: hypoxia-inducible factor $1 a$; mTOR: Mammalian target of rapamycin; MAPK: Mitogen-activated protein kinase; MEK: MAP kinase kinase; NDRI: National Disease Research Interchange; PAs: pulmonary arteries; PAVSM: Pulmonary arterial vascular smooth muscle; PDGF: platelet-derived growth factor; PH: Pulmonary hypertension; PKA: Protein kinase A RTK: Receptor tyrosine kinase; S6K1: p70 S6 kinase 1.

\section{Competing interests}

The authors declare that they have no competing interests.

\section{Authors' contributions}

EAG performed statistical analysis, participated in study coordination and drafted the manuscript. ISK carried out the immunoblots and participated in the statistical analysis of immunoblots. DAG carried out DNA synthesis experiments and participated in the statistical analysis of DNA synthesis data. VPK designed and coordinated the study and revised the manuscript. All authors read and approved the final manuscript.

\section{Acknowledgements}

We thank the National Disease Research Interchange (NDRI) for providing us with human lung tissue and Ms. Mary McNichol for critical reading of the manuscript. This work is supported by Sepracor (V.P.K.) and, in part, by a Gilead Science Research Award (E.A.G.), an American Lung Association Research Award (E.A.G.), the University of Pennsylvania Research Foundation (E.A.G.), and NIH/NHLBI 1R01HL113178 (E.A.G).

\section{Author details}

${ }^{1}$ Pulmonary, Allergy \& Critical Care Division, Department of Medicine, University of Pennsylvania Perelman School of Medicine, Philadelphia, PA USA. ${ }^{2}$ Penn Cardiovascular Institute, University of Pennsylvania, Philadelphia, PA, USA. ${ }^{3}$ Abramson Cancer Center, University of Pennsylvania, Philadelphia, PA, USA. ${ }^{4}$ University of Pennsylvania, Perelman School of Medicine, Translational Research Laboratories, Room 1214, 125 South 31st Street, Philadelphia 19104, PA

Received: 14 February 2012 Accepted: 3 September 2012 Published: 27 November 2012

\section{References}

1. Newman JH: Pulmonary hypertension. Am J Respir Crit Care Med 2005, 172:1072-1077.

2. Stenmark KR, Fagan KA, Frid MG: Hypoxia-induced pulmonary vascular remodeling: cellular and molecular mechanisms. Circ Res 2006, 99:675-691.

3. Barbera JA, Peinado VI, Santos S: Pulmonary hypertension in chronic obstructive pulmonary disease. Eur Respir J 2003, 21:892-905.

4. Incalzi RA, Fuso L, De Rosa M, Di Napoli A, Basso S, Pagliari G, Pistelli R: Electrocardiographic signs of chronic cor pulmonale: a negative prognostic finding in chronic obstructive pulmonary disease. Circulation 1999, 99:1600-1605.

5. Mandegar M, Fung YB, Huang W, Remillard CV, Rubin LJ, Yuan JXJ: Cellular and molecular mechanisms of pulmonary vascular remodeling: role in the development of pulmonary hypertension. Microvasc Res 2004, 68:75-103.

6. Elwing J, Panos RJ: Pulmonary hypertension associated with COPD. Int J Chron Obstruct Pulmon Dis 2008, 3:55-70.

7. Hewer RC, Sala-Newby GB, Wu YJ, Newby AC, Bond M: PKA and Epac synergistically inhibit smooth muscle cell proliferation. J Mol Cell Cardiol 2011, 50:87-98.

8. Mhanna MJ, Koester JF, Cohn RC: Effects of $(R, R)$ - and $(R, R / S, S)$-formoterol on airway relaxation and contraction in an experimental rat model. Curr Ther Res 2007, 68:249-261.

9. Roth M, Johnson PRA, Rüdiger JJ, King GG, Ge Q, Burgess JK, Anderson G, Tamm M, Black JL: Interaction between glucocorticoids and beta-2 agonists on bronchial airway smooth muscle cells through synchronised cellular signalling. Lancet 2002, 360:1293-1299.
10. Haynes J, Robinson J, Saunders L, Taylor AE, Strada SJ: Role of cAMPdependent protein kinase in CAMP-mediated vasodilation. Am J Physiol Heart Circ Physiol 1992, 262:H511-H516.

11. Tantini B, Manes A, Fiumana E, Pignatti C, Guarnieri C, Zannoli R, Md AB, Galiè N: Antiproliferative effect of sildenafil on human pulmonary artery smooth muscle cells. Bas Res Cardiol 2005, 100:131-138.

12. Aalbers R, Ayres J, Backer V, Decramer M, Lier PA, Magyar P, Malolepszy J, Ruffin R, Sybrecht GW: Formoterol in patients with chronic obstructive pulmonary disease: a randomized, controlled, 3-month trial. Eur Respir J 2002, 19:936-943.

13. van Noord JA, Aumann JL, Janssens E, Verhaert J, Smeets JJ, Mueller A, Cornelissen PJG: Effects of tiotropium with and without formoterol on airflow obstruction and resting hyperinflation in patients with copd. Chest 2006, 129:509-517.

14. Descalzi D, Folli C, Nicolini G, Riccio AM, Gamalero C, Scordamaglia F, Canonica GW: Anti-proliferative and anti-remodelling effect of beclomethasone dipropionate, formoterol and salbutamol alone or in combination in primary human bronchial fibroblasts. Allergy 2008 63:432-437.

15. Stork PJS, Schmitt JM: Crosstalk between CAMP and MAP kinase signaling in the regulation of cell proliferation. Trends Cell Biol 2002, 12:258-266.

16. Cook SJ, McCormick F: Inhibition by CAMP of Ras-dependent activation of Raf. Science 1993, 262:1069-1072.

17. Mischak H, Seitz T, Janosch P, Eulitz M, Steen H, Schellerer M, Philipp A, Kolch W: Negative regulation of Raf-1 by phosphorylation of serine 621 . Mol Cell Biol 1996, 16:5409-18.

18. Wang Z, Dillon TJ, Pokala V, Mishra S, Labudda K, Hunter B, Stork PJS: Rap1mediated activation of extracellular signal-regulated kinases by cyclic AMP is dependent on the mode of Rap1 activation. Mol Cell Biol 2006, 26:2130-2145.

19. Giasson E, Servant MJ, Meloche S: Cyclic AMP-mediated inhibition of angiotensin II-induced protein synthesis Is associated with suppression of tyrosine phosphorylation signaling in vascular smooth muscle cells. J Biol Chem 1997, 272:26879-26886

20. Goncharova EA, Ammit AJ, Irani C, Carroll RG, Eszterhas AJ, Panettieri RA, Krymskaya VP: $\mathrm{PI} 3 \mathrm{~K}$ is required for proliferation and migration of human pulmonary vascular smooth muscle cells. Am J Physiol Lung Cell Mol Physiol 2002, 283:L354-363.

21. Humar R, Kieffer FN, Berns H, Resink TJ, Battegay EJ: Hypoxia enhances vascular cell proliferation and angiogenesis in vitro via rapamycin (mTOR)-dependent signaling. FASEB J 2002, 16:771-780.

22. Kingsley K, Huff JL, Rust WL, Carroll K, Martinez AM, Fitchmun M, Plopper GE: ERK1/2 mediates PDGF-BB stimulated vascular smooth muscle cel proliferation and migration on laminin-5. Biochem Biophys Res Commun 2002, 293:1000-1006.

23. Isenović ER, Kedees MH, Haidara MA, Trpkovic A, Mikhailidis DP, Marche P: Involvement of ERK1/2 kinase in insulin-and thrombin-stimulated vascular smooth muscle cell proliferation. Angiology 2010, 61:357-364.

24. Preston IR, Hill NS, Warburton RR, Fanburg BL: Role of 12-lipoxygenase in hypoxia-induced rat pulmonary artery smooth muscle cell proliferation Am J Physiol Lung Cell Mol Physiol 2006, 290:L367-374.

25. Krymskaya VP, Snow J, Cesarone G, Khavin I, Goncharov DA, Lim PN, Veasey SC, Ihida-Stansbury K, Jones PL, Goncharova EA: mTOR is required for pulmonary arterial vascular smooth muscle cell proliferation under chronic hypoxia. FASEB J 2011, 25:1922-1933.

26. Goncharova EA, Goncharov DA, Li H, Pimtong W, Lu S, Khavin I, Krymskaya VP: $\mathrm{mTORC2}$ is required for proliferation and survival of TSC2-Null Cells. Mol Cell Biol 2011, 31:2484-2498.

27. Nishimura T, Faul JL, Berry GJ, Veve I, Pearl RG, Kao PN: 40-0-(2-Hydroxyethyl)-rapamycin attenuates pulmonary arterial hypertension and neointimal formation in rats. Am J Respir Crit Care Med 2001, 163:498-502

28. Paddenberg $\mathrm{R}$, Stieger $\mathrm{P}$, von Lilien A, Faulhammer $\mathrm{P}$, Goldenberg A Tillmanns H, Kummer W, Braun-Dullaeus R: Rapamycin attenuates hypoxiainduced pulmonary vascular remodeling and right ventricular hypertrophy in mice. Respir Res 2007, 8:15.

29. Wessler JD, Steingart RM, Schwartz GK, Harvey BG, Schaffer W: Dramatic improvement in pulmonary hypertension with rapamycin. Chest 2010 138:991-993.

30. Sarbassov DD, Guertin DA, Ali SM, Sabatini DM: Phosphorylation and regulation of Akt/PKB by the rictor-mTOR complex. Science 2005, 307:1098-1101. 
31. Morrell NW, Adnot S, Archer SL, Dupuis J, Jones PL, MacLean MR, McMurtry IF, Stenmark KR, Thistlethwaite PA, Weissmann N, Yuan JXJ, Weir EK: Cellular and molecular basis of pulmonary arterial hypertension. J Am Coll Cardiol 2009, 54:S20-S31.

32. Wouters $B G$, Koritzinsky M: Hypoxia signalling through mTOR and the unfolded protein response in cancer. Nat Rev Cancer 2008, 8:851-864.

33. Pak O, Aldashev A, Welsh D, Peacock A: The effects of hypoxia on the cells of the pulmonary vasculature. Eur Respir J 2007, 30:364-372.

34. Stenmark KR, Meyrick B, Galie N, Mooi WJ, McMurtry IF: Animal models of pulmonary arterial hypertension: the hope for etiological discovery and pharmacological cure. Am J Physiol Lung Cell Mol Physiol 2009, 297:L1013-1032.

35. Cheng SWY, Fryer LGD, Carling D, Shepherd PR: Thr2446 Is a novel mammalian target of rapamycin (mTOR) phosphorylation site regulated by nutrient status. J Biol Chem 2004, 279:15719-15722.

36. Goncharova EA, Lim P, Goncharov DA, Eszterhas A, Panettieri RA Jr, Krymskaya VP: Assays for in vitro monitoring of proliferation of human airway smooth muscle (ASM) and human pulmonary arterial vascular smooth muscle (VSM) cells. Nat Prot 2006, 1:2905-2908.

37. Goncharova EA, Goncharov DA, Eszterhas A, Hunter DS, Glassberg MK, Yeung RS, Walker CL, Noonan D, Kwiatkowski DJ, Chou MM, Panettieri RA, Krymskaya VP: Tuberin regulates p70 S6 kinase activation and ribosomal protein S6 phosphorylation: a role for the TSC2 tumor suppressor gene in pulmonary lymphangioleiomyomatosis. J Biol Chem 2002, 277:30958-30967.

38. Goncharova EA, Goncharov DA, Damera G, Tliba O, Amrani Y, Panettieri RA, Krymskaya VP: STAT3 is required for abnormal proliferation and survival of TSC2-deficient cells: relevance to pulmonary LAM. Mol Pharmacol 2009, 76:766-777.

39. Barst RJ: PDGF signaling in pulmonary arterial hypertension. J Clin Invest 2005, 115:2691-2694.

40. Chaouat A, Weitzenblum E, Higenbottam T: The role of thrombosis in severe pulmonary hypertension. Eur Respir J 1996, 9:356-363.

41. Newman JH, Fanburg BL, Archer SL, Badesch DB, Barst RJ, Garcia JGN, Kao PN, Knowles JA, Loyd JE, McGoon MD, Morse JH, Nichols WC, Rabinovitch M, Rodman DM, Stevens T, Tuder RM, Voelkel NF, Gail DB: Pulmonary arterial hypertension: future directions: report of a national heart, lung and blood institute/office of rare diseases workshop. Circulation 2004, 109:2947-2952.

42. Trofast J, ÖSterberg K, Källström BL, Waldeck B: Steric aspects of agonism and antagonism at $\beta$-adrenoceptors: Synthesis of and pharmacological experiments with the enantiomers of formoterol and their diastereomers. Chirality 1991, 3:443-450.

43. Mizuno S, Kadowaki M, Demura Y, Ameshima S, Miyamori I, Ishizaki T: p42/44 mitogen-activated protein kinase regulated by p53 and nitric oxide in human pulmonary arterial smooth muscle cells. Am J Respir Cell Mol Biol 2004, 31:184-192.

44. Li B, Yang L, Shen J, Wang C, Jiang Z: The antiproliferative effect of sildenafil on pulmonary artery smooth muscle cells is mediated via upregulation of mitogen-activated protein kinase phosphatase- 1 and degradation of extracellular signal-regulated kinase 1/2 phosphorylation. Anesth Analg 2007, 105:1034-1041.

45. Stenmark KR, McMurtry IF: Vascular remodeling versus vasoconstriction in chronic hypoxic pulmonary hypertension: a time for reappraisal? Circ Res 2005, 97:95-98.

46. Hassoun PM, Mouthon L, Barberà JA, Eddahibi S, Flores SC, Grimminger F, Jones PL, Maitland ML, Michelakis ED, Morrell NW, Newman JH, Rabinovitch M, Schermuly RT, Stenmark KR, Voelkel NF, Yuan JXJ, Humbert M: Inflammation, growth factors, and pulmonary vascular remodeling. J Am Coll Cardiol 2009, 54:S10-S19.

47. Qin L, D'Alessandro-Gabazza CN, Aoki S, Gil-Bernabe P, Yano Y, Takagi T, Boveda-Ruiz D, Ramirez Marmol AY, San Martin Montenegro VT, Toda M, Miyake Y, Taguchi O, Takei Y, Morser J, Gabazza EC: Pulmonary hypertension is ameliorated in mice deficient in thrombin-activatable fibrinolysis inhibitor. J Thromb Haemost 2010, 8:808-816.

48. Wu YJ, Bond M, Sala-Newby GB, Newby AC: Altered S-phase kinaseassociated protein-2 levels are a major mediator of cyclic nucleotideinduced inhibition of vascular smooth muscle cell proliferation. Circ Res 2006, 98:1141-1150

49. Indolfi C, Avvedimento EV, Di Lorenzo E, Esposito G, Rapacciuolo A, Giuliano P, Grieco D, Cavuto L, Stingone AM, Ciullo I, Condorelli G, Chiariello M:
Activation of cAMP-PKA signaling in vivo inhibits smooth muscle cell proliferation induced by vascular injury. Nat Med 1997, 3:775-779.

50. Calipel A, Mouriaux F, Glotin AL, Malecaze F, Faussat AM, Mascarelli F: Extracellular signal-regulated kinase-dependent proliferation is mediated through the protein kinase A/B-Raf pathway in human uveal melanoma cells. J Biol Chem 2006, 281:9238-9250.

51. Frey N, Olson EN: Cardiac hypertrophy: the good, the bad, and the ugly. Ann Rev Physiol 2003, 65:45-79.

52. Misra UK, Kaczowka S, Pizzo SV: The cAMP-activated GTP exchange factor, Epac1 upregulates plasma membrane and nuclear Akt kinase activities in 8-CPT-2-O-Me-cAMP-stimulated macrophages: Gene silencing of the CAMP-activated GTP exchange Epac1 prevents 8-CPT-2-O-Me-cAMP activation of Akt activity in macrophages. Cell Signal 2008, 20:1459-1470.

53. Misra UK, Pizzo SV: Epac1-induced cellular proliferation in prostate cancer cells is mediated by B-Raf/ERK and mTOR signaling cascades. J Cell Biochem 2009, 108:998-1011.

54. Delmotte P, Sanderson MJ: Effects of formoterol on contraction and ca2+ signaling of mouse airway smooth muscle cells. Am J Respir Cell Mol Biol 2010, 42:373-381.

55. Wettschureck N, Offermanns S: Mammalian G proteins and their cell type specific functions. Physiol Rev 2005, 85:1159-1204.

56. Cazzola M, Mantero A, Santus P, Carlucci P, Mondoni M, Bosotti L, Centanni $S$ : Doppler echocardiographic assessment of the effects of inhaled longacting $\beta 2$-agonists on pulmonary artery pressure in COPD patients. Pulm Pharmacol Ther 2007, 20:258-264.

57. Anand-Srivastava MB: Enhanced expression of inhibitory guanine nucleotide regulatory protein in spontaneously hypertensive rats. Relationship to adenylate cyclase inhibition. Biochem J 1992, 288:79-85.

58. Anand-Srivastava MB, Picard S, Thibault C: Altered expression of inhibitory guanine nucleotide regulatory proteins ( $\mathrm{Gi}$ alpha) in spontaneously hypertensive rats. Am J Hypertens 1991, 10:840-843.

59. Li Y, Anand-Srivastava MB: Inactivation of enhanced expression of gi proteins by pertussis toxin attenuates the development of high blood pressure in spontaneously hypertensive rats. Circ Res 2002, 91:247-254

60. Goncharova E, Vorotnikov AV, Gracheva EO, Wang CLA, Panettieri RA, Stepanova W, Tkachuk VA: Activation of p38 MAP-kinase and caldesmon phosphorylation are assential for urokinase-induced human smooth muscle cell migration. Biol Chem 2002, 383:115-126.

61. Dumaz N, Marais R: Protein kinase a blocks raf-1 activity by stimulating 14-3-3 binding and blocking raf-1 interaction with ras. J Biol Chem 2003, 278:29819-29823.

62. Häfner S, Adler HS, Mischak H, Janosch P, Heidecker G, Wolfman A, Pippig S, Lohse $M$, Ueffing $M$, Kolch W: Mechanism of inhibition of Raf-1 by protein kinase A. Mol Cel Biol 1994, 14:6696-6703.

63. Beeram M, Patnaik A, Rowinsky EK: Raf: a strategic target for therapeutic development against cancer. J Clin Oncol 2005, 23:6771-6790.

64. Romano D, Pertuit M, Rasolonjanahary R, Barnier JV, Magalon K, Enjalbert A, Gerard C: Regulation of the RAP1/RAF-1/extracellularly regulated kinase$1 / 2$ cascade and prolactin release by the phosphoinositide 3-kinase/AKT pathway in pituitary cells. Endocrinology 2006, 147:6036-6045.

65. Archer SL, Gomberg-Maitland M, Maitland ML, Rich S, Garcia JGN, Weir EK: Mitochondrial metabolism, redox signaling, and fusion: a mitochondriaROS-HIF-1a-Kv1.5 O2-sensing pathway at the intersection of pulmonary hypertension and cancer. Am J Physiol Heart Circ Physiol 2008, 294:H570-H578.

66. Richard DE, Berra E, Gothié E, Roux D, Pouysségur J: p42/p44 Mitogenactivated protein kinases phosphorylate hypoxia-inducible factor 1a (HIF-1a) and enhance the transcriptional activity of HIF-1. J Biol Chem 1999, 274:32631-32637.

67. Mylonis I, Chachami G, Samiotaki M, Panayotou G, Paraskeva E, Kalousi A, Georgatsou E, Bonanou S, Simos G: Identification of MAPK phosphorylation sites and their role in the localization and activity of hypoxia-inducible factor-1a. J Biol Chem 2006, 281:33095-33106.

68. Sang N, Stiehl DP, Bohensky J, Leshchinsky I, Srinivas V, Caro J: MAPK signaling up-regulates the activity of hypoxia-inducible factors by its effects on p300. J Biol Chem 2003, 278:14013-14019.

69. Lauzier MC, Pagé EL, Michaud MD, Richard DE: Differential regulation of hypoxia-inducible factor- 1 through receptor tyrosine kinase transactivation in vascular smooth muscle cells. Endocrinology 2007, 148:4023-4031. 
70. Monfar M, Lemon KP, Grammer TC, Cheatham L, Chung J, Vlahos CJ, Blenis J: Activation of pp 70/85 S6 kinases in interleukin-2-responsive lymphoid cells is mediated by phosphatidylinositol 3-kinase and inhibited by cyclic AMP. Mol Cel Biol 1995, 15:326-37.

71. Kahan C, Seuwen K, Meloche S, Pouysségur J: Coordinate, biphasic activation of p44 mitogen-activated protein kinase and S6 kinase by growth factors in hamster fibroblasts. Evidence for thrombin-induced signals different from phosphoinositide turnover and adenylylcyclase inhibition. J Biol Chem 1992, 267:13369-75.

doi:10.1186/1465-9921-13-109

Cite this article as: Goncharova et al:: Differential effects of formoterol on thrombin- and PDGF-induced proliferation of human pulmonary arterial vascular smooth muscle cells. Respiratory Research 2012 13:109.

\section{Submit your next manuscript to BioMed Central and take full advantage of:}

- Convenient online submission

- Thorough peer review

- No space constraints or color figure charges

- Immediate publication on acceptance

- Inclusion in PubMed, CAS, Scopus and Google Scholar

- Research which is freely available for redistribution 